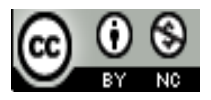

Jurnal Pendidikan Dasar Indonesia is licensed under

A Creative Commons Attribution-Non Commercial 4.0 International License

\title{
ANALYSIS LEARNING SOCIAL SCIENCE CHARGED THE VALUES OF ENTREPRENEURSHIP IN PRIMARY SCHOOL (Case Study in Social Science Education in Class IV SDPN Pajagalan 58 Bandung)
}

\author{
Dadang Iskandar ${ }^{1)}$, Lutma Ranta Allolinggi ${ }^{2)}$, Acep Roni Hamdani ${ }^{3)}$ \\ 1) Universitas Pasundan \\ E-mail:dang_isk@yahoo.com \\ 2) Universitas Kristen Indonesia Toraja \\ E-mail: lutmaranta@gmail.com \\ 3) Universitas Pasundan \\ E-mail: acepronihamdani@unpas.ac.id
}

\begin{abstract}
Entrepreneurship education is a government program that is conducted every level of education. Implementation of the values of entrepreneurship learning in primary schools is an effort to promote entrepreneurship, so that people can develop into a reliable personal and be the generation that can create jobs. This study aims to assess the extent to which the learning of Social Sciences can provide space in growing the value of entrepreneurship in primary school students. This research was conducted in SDPN Pajagalan 58 with qualitative approach case study method. The subject is the person responsible for entrepreneurship education program, one teacher of Social Sciences and seventeen students of class IV. Based on the survey results revealed that entrepreneurship education program has been designed as possible into school programs that are implemented on an ongoing basis. The values of entrepreneurship has been published in school activities such as extracurricular activities, events and activities programmed habituation. Planning learning Social Sciences laden entrepreneurial values starting from the manufacture of the syllabus and lesson plans. Implementation of classroom learning is done in accordance with the lesson plan gives more space for students to develop a personality. Assessment of learning laden entrepreneurial values is done through observation and checks on student attendance. At the time of the learning takes place, the student has demonstrated an attitude / entrepreneurial character that is honest, self-discipline, confidence, leadership, creative, independent, hard work, responsibility, curiosity, communicative, and cooperation. The main problem is the plan that is prepared teacher is not maximized and not yet fully apply in learning. From the results of this study are expected to provide benefits for the development of entrepreneurship education in primary schools, especially in SDPN Pajagalan 58 and become material for the evaluation of Bandung City Education Department.
\end{abstract}

Keywords: Learning Social Sciences, Entrepreneurship Education, Elementary School

\section{INTRODUCTION}

Education is a conscious and planned effort in the process of coaching and learning for individuals to grow into a human, independent, responsible, creative, knowledgeable, healthy and moral (character) noble.

One part of the national education system announced by the government is an entrepreneurial education program.
The program is conducted from early childhood, elementary, middle, and high school and even up to the university. This is in line with the grain of national policies in the field of education contained in the document of the National Medium Term Development Plan (RPJMN) 2010-2014, realms 2, namely: increased access to quality education, affordable, relevant, and efficient towards the lifting of the welfare of the people, independence, nobility of character, and a strong national character. 
Furthermore, with regard to entrepreneurial system Suryana (2011: 37) explains that;

In entrepreneurship, pragmatic primary value system can be seen from the character, spirit, and behavior, for example, always working hard, firm, prioritizing achievement, courage to take risks, productivity, creativity, innovation, quality of work, commitment, and ability to find opportunities. Furthermore, moralistic values include the belief or the confidence, respect, trust, cooperation, honesty, exemplary, and virtue.

Thus the entrepreneur has a goal-oriented progress to obtain the material, with the characteristics: risk-taking, open to technology, and prioritizing material (Chakravarthy and Lorange, 2008). Besides, entrepreneurs have a goaloriented progress but not to pursue the matter (Chesbrough, 2012). For entrepreneurs like this just want to create a sense of responsibility, service, positive attitude, and creativity, and just based on the habits of existing ones, such as venture with the calculation of horoscope, other calculations, and fengshui order to succeed (Henry, Hill, \& Leitch , 2005).

Elementary School as a most basic level of formal education in Indonesia is expected to provide space in the development of entrepreneurship education as part of government efforts to promote entrepreneurship in education. Learning system in elementary school is now guided by the curriculum of 2006 (KTSP) which contains the terms of reference in which includes content standards.

There are a number of subjects in charge of the curriculum is taught in primary schools, which are the subjects of Social Science Knowledge. The learning objectives Social Science Knowledge in primary schools is oriented to three aspects of cognitive, affective, and psychomotor. Knowledge in the Social Sciences learning in primary school during this cognitive and psychomotor achieved well but the affective aspect is still less than the maximum because the learning system only finishing material.

Based on information from Bandung City Education Department in getting information about institutions into pilot schools (Pilot Project) government in developing the educational program the values of entrepreneurship at primary school level. The school is SDPN Pajagalan 58 Bandung. From interviews with Mr. Eko Setiawan researchers as deputy head SDPN Pajagalan 58 and also in charge of Entrepreneurship Education program, the researchers obtained information that:

Values education program of entrepreneurship in SDPN Pajagalan 58 has been implemented from the academic year 2010/2011, 2011/2012 and 2012/2013 academic year. Planting the values of entrepreneurship in students SDPN Pajagalan 58 already obtain satisfactory results, but still continue to be developed to obtain better results again.

Based on this information, researchers conducted a study of the extent to which SDPN Pajagalan 58make room for values education in learning entrepreneurship in Social ScienceKnowledge, as part of government efforts to promote entrepreneurship.

\section{METHODS}

Analysis of Social Knowledge Learning Sciences charged the values of entrepreneurship in primary school students is a research using a qualitative approach with case study method. A qualitative approach has implications for the use of standard size and qualitative and conducted through case studies (Thomas, 2006). The case study aims to gain a deep understanding of the objective conditions in the elementary school students familiarize civilize entrepreneurial values in students' everyday lives.

This research was conducted in a natural setting that is not in a setting that is designed in such a way as is done in quantitative research. In practice, researchers mingling with students, teachers and the elements of the other schools to get the data and information needed. Researchers trying to blend directly in social situations in the environment SDPN Pajagalan 58.

Subjects in this study are the stakeholders who have different characteristics, elements, and the value associated with the understanding of the values of entrepreneurship contained in Social ScienceKnowledge learning in primary schools. Therefore, the subjects in this study were teachers who numbered one person and grade IV/A, amounting to thirty-four. Of the thirty-four students have then taken the sample (respondents) in an effort to facilitate and focus the observation research. At the preliminary study stage, the determination of the subject of research done by purposive Sampling (Zainal Arifin, 2012: 221) subjects who have considered able to provide information relevant to the values of entrepreneurship. They consist of the principal, who is responsible entrepreneurship programs, teacher of Social Science Knowledge and graders IVA seventeen students were given a short code Students in SW (SW 1 to SW 17).

The main data sources are the words and actions of those who observed or interviewed in the neighborhood SDPN Pajagalan 58, recorded through written notes, recording video and taking pictures with a camera and or HP. Sources of data in addition to the words and actions in this study, also sentences, paragraphs and discourse found in the literature or documentation related to the values of entrepreneurship.

\section{RESULTS AND DISCUSSION}

Curriculum SDPN Pajagalan 58 as part of the planning process of learning and teaching within a school year covers a number of subjects whose breadth and depth is the burden of learning for students and local content material. Consists of mandatory subjects: religious education, civic education, the Indonesian language, math, science, Knowledge Science Social, cultural arts and physical education, sports and health.

Selected local content defined by characteristic, potential and advantages of the region, as well as the availability of land, infrastructure, and educators. Target local content 
lessons is the development of entrepreneurship and the cultivation of cultural values in accordance with the environment. The values of entrepreneurship being developed include innovation, creativity, critical thinking, exploration, communication, independence, and work ethic. Cultural values in question include honesty, responsibility, discipline, sensitivity to the environment, and cooperation. Planting entrepreneurial values and culture are integrated in the learning process that is conditioned so that these values can be attitudes and behavior in everyday life (Gehman, 2013)

As a pilot piloting schools Culture and National Character Education, Entrepreneurship and Creative Economy designated by the Curriculum Center, SDPN Pajagalan 58 task severe enough to produce students who have the character and values of culture and entrepreneurship. Piloting responsibility as a school to make all elements of the school to work together to realize the achievement of objectives of the program. The first thing that is visible curriculum SDPN Pajagalan 58 which had been adjusted with the task as piloting school in it states clearly the character and values of entrepreneurship.

Documentation of the results found that the value of entrepreneurship has been included in the school curriculum as a whole and in the syllabus and lesson plans contained suitable themes of learning (SK and KD). But as the school Piloting SDPN Pajagalan 58 designing and prioritize four values that will be implemented and developed in the school program that is religious value, care for the environment, communicative and innovative. This is done in an effort to not just load these values into the learning but rather the civilizing values in the student (Authors, 2012). With four prioritize these values in the learning process teachers are expected to provide conclusions / considerations expressed in a qualitative statement to each student as follows:

1. BT: Not Seen (if the students do not show early signs of behavior that is expressed in the indicator).

2. MT: Start Seen (if the students are already starting to show early signs of behavior that is expressed in the indicator but not consistently)

3. MB: Start Developing (if the students are already showing signs of behavior that is expressed in the indicator and start consistently)

4. MK: entrenched (if the students continuously exhibits behavior consistently expressed in the indicator)

In the learning that takes place in the classroom, the teacher's role is also very helping students to cultivate an entrepreneurial attitude. The value of entrepreneurship in teaching Social Sciences Knowledge is intended as a set of beliefs or principles that have mempribadi behaviors in students that can be revealed through thoughts and actions. Sapriya (2011), suggests that;

program learning Knowledge of Social Sciences should provide the opportunity for students to express, reflect and articulate the values that dianutnyaâ. This process depends on the values of procedural class.
From these explanations it appears that learning Social Science Knowledge provides space for the planting of values to every child, including the value of entrepreneurship (McClintock \& Allison, 1989). For planting or learning in school grades were not necessarily done separately, but the values that are taught inherent in any learning materials that have been in school (Chang Kao, Chu, \& Chiu, 2009).

The values of entrepreneurship in science learning in class IV Social Science Knowledge can be seen as a good teacher teaching staff, as well as to students as learners. In planting the value of entrepreneurship, the teacher shows the attitudes that correspond to the value of entrepreneurship, for example, disciplined, creative, leadership and other values. Of the students also appear to be so, that shows the attitude of discipline, hard work, teamwork, leadership, honest, creative, self-confident, independent and attitude / other value. These values can be seen through observation, interviews and discussions by researchers during field with teachers and students in the class.

But at the level of implementation of learning in SDPN Pajagalan 58 there are some things that still need to get more attention from the parties involved, in particular Puskur and Responsible Entrepreneurship Program Pendidikian. Things researchers found that the curriculum, syllabus and RPP in SDPN Pajagalan 58 which have been made yet sikron with real learning is good. Although at this stage of implementation in the classroom students have shown an attitude that shows entrepreneurial souls. But attitudes / values that will be embedded properly planning really focused and observed continuously.

\section{IV.CONCLUSION}

After doing research on learning Knowledge Social Science charged entrepreneurial values in the fourth grade of elementary school students, including lesson planning, implementation of learning, assessment, and problems and solutions faced in the study, the researchers draw the following conclusion:

1. entrepreneurship education programs in SDPN Pajagalan 58 have executed well in the overall school environment through habituation and extracurricular programs implemented continuously every week according to the schedule specified.

2. Development of entrepreneurship education programs in primary schools if continuously improved to be able to equip learners from scratch and mold them to have entrepreneurial spirit to achieve public welfare and good economic growth.

3. Social Sciences Knowledge Learning has provided room for the development of entrepreneurship in primary school grades so that students are more active during the learning progresses and more teachers become facilitators for students.

4. Planning Knowledge Learning Social Studies class IV uncharged elementary school entrepreneurial values carried through the following steps: 
a. Assess Competency Standards (SK) and the Basic Competency (KD) to determine whether the values of entrepreneurship is included therein.

b. Lists the values of entrepreneurship that have been listed in SK and KD into the syllabus.

c. Developing a learning step active learners enable learners have the opportunity to integrate values and show it in behavior.

d. Incorporate step integrated active learning entrepreneurial values into the RPP that is disciplined, creative, hard working, honest, confident, communicative, leadership and cooperation.

\section{REFERENCES}

Arifin, Zainal. (2012). Evaluasi Pembelajaran (Prinsip, Teknik, Prosedur). Bandung: PT. Remaja Rosdakarya.

Bapenas. (2010). Peraturan Presiden No. 5 tentang Tahun 2010 tentang Rencana Pembangunan Jangka Menengah Nasional 2010 - 2014. Jakarta : Bapenas

Kemendiknas.(2006). Undang-undang No. 20 Tahun 2003 tentang Sistem Pendidikan Nasional. Jakarta: Kemendiknas

Pusat Kurikulum.(2010). Pendidikan Kewirausahaan. Jakarta: Pusat Kurikulum

Sapriya. (2011). Pendidikan Ilmu Pengetahun Sosial. Bandung. PT Remaja Rosdakarya.

Supriatna, Nana. dkk. (2009). Pendidikan Ilmu Pengetahun Sosial di $S D$. Bandung: UPI PRESS.

Suryana, (2006). Kewirausahaan Pedoman Praktis; Kiat Dan Proses Menuju Sukses. Jakarta: Salemba Empat.

Sugiyono. (2012). Metode Penelitian Pendidikan (Pendekatan Kuantitatif, Kualitatif, dan $R \& D$ ). Bandung: Alfabeta.

Chakravarthy, B., \& Lorange, P. (2008). Driving renewal: the entrepreneur-manager. Journal of Business Strategy, 29(2), 14-21. https://doi.org/10.1108/02756660810858116

Chesbrough, H. (2012). Open Innovation: Where We've Been and Where We're Going. Research-Technology Management, 55(4), 20-27. https://doi.org/10.5437/08956308X5504085

Gehman, J. (2013). Values Work: a Process Study of the Emergence and Performance of Organizational Values Practices, 56(1), 84-112.

Thomas, D. R. (2006). A General Inductive Approach for Analyzing Qualitative Evaluation Data. American Journal of Evaluation, 27(2), 237-246. https://doi.org/10.1177/1098214005283748 